\title{
Skuteczność terapii pomalidomidem u pacjenta ze szpiczakiem plazmocytowym opornym na inne leki immunomodulujące
}

\section{Effectiveness of pomalidomide therapy in patient with multiple myeloma refractory to other immunomodulatory drugs}

\author{
Marta Masternak (D), Marta Morawska (1) \\ Centrum Onkologii Ziemi Lubelskiej im. św. Jana z Dukli w Lublinie \\ Zakład Hematoonkologii Doświadczalnej Uniwersytetu Medycznego w Lublinie
}

\begin{abstract}
Streszczenie
Leczenie pacjentów z nawrotowym lub opornym na leczenie szpiczakiem plazmocytowym (MM) jest dużm wyzwaniem terapeutycznym. Wprowadzenie do terapii nowych aktywnych leków, należacych między innymi do klas leków immunomodulujacych (IMiD) i inhibitorów proteasomu, przyczynito sie do znacznego wzrostu odsetka $i$ jakości uzyskiwanych odpowiedzi oraz, co najwazniejsze, wydtużenia życia pacjentów. Należy jednak pamietać, ze MM jest choroba powodujaca czeste progresje, zaś wybór odpowiedniej strategii leczenia jest znacznie trudniejszy wraz z kolejnymi nawrotami. Do leków stosowanych w takich przypadkach należy między innymi. pomalidomid - IMiD zarejestrowany $w$ Polsce, poczqwszy od III linii leczenia dla pacjentów $z$ nawrotowym $i$ opornym na leczenie MM.
\end{abstract}

W pracy opisano 66-letniq pacjentke z rozpoznanym MM IgG lambda, u której od stycznia 2016 roku stosowano piéc linii leczenia za pomoca IMiD, bortezomibu i daratumumabu, nie uzyskujac odpowiedzi na leczenie. W maju 2019 roku pacjentke zakwalifikowano do dalszego leczenia pomalidomidem $w$ skojarzeniu z matymi dawkami doustnego deksametazonu (POM-DEX). W trakcie leczenia obserwowano znaczna redukcje steżenia biatka monoklonalnego IgG lambda. Po otrzymaniu dwóch cykli terapii pacjentka spetnita kryteria czésciowej remisji, a po 12 cyklach leczenia steżenie biatka monoklonalnego obniżyto sie o $78 \%$ wzgledem okresu sprzed leczenia. Tolerancja leczenia byta dość dobra. Jedynymi objawami niepożadanymi obserwowanymi w trakcie leczenia pozostawaty zwięsszenie masy ciała oraz niewielkie obrzeki podudzi.

Dzięki zastosowaniu schematu POM-DEX u pacjentki osiagnięto trwata odpowiedź na leczenie, mimo szybkich nawrotów choroby w trakcie wcześniejszych linii leczenia.

Słowa kluczowe: szpiczak plazmocytowy, pomalidomid, leki immunomodulujące

Hematologia 2020; 11, 4: 235-239

Abstract

Treatment of patients with refractory or relapse multiple myeloma (MM) is a major therapeutic challenge. The introduction to the therapy of new active drugs, such as immunomodulating drugs (IMiDs) or proteasome inhibitors contributed to a significant increase in the percentage and quality

Adres do korespondencji: Marta Masternak, Centrum Onkologii Ziemi Lubelskiej im. św. Jana z Dukli, ul. Jaczewskiego 7, 20-090 Lublin, e-mail: podgorniakmarta@gmail.com 
of the obtained responses and, most importantly, to the prolongation of patients' life. However, $M M$ is a disease with frequent progressions, and choosing the right treatment strategy is much more difficult with each subsequent relapse. The drugs used in the treatment of such patients include pomalidomide - an IMiD, registered in Poland as the third-line therapy for patients with relapsed and refractory $M M$.

The paper presents a case report of a 66-year-old patient diagnosed with IgG lambda MM, who since January 2016 had received 5 lines of treatment with IMiDs, bortezomib and daratumumab, nevertheless she had not met the criteria of response to treatment. In May 2019, the patient was qualified for further treatment with pomalidomide in combination with low doses of oral dexamethasone (POM-DEX). During the treatment, a significant reduction in the level of the monoclonal IgG lambda protein was observed. After receiving two treatment cycles, the patient met the criteria for partial remission, and after 12 cycles the level of monoclonal protein decreased by $78 \%$ compared to the period before treatment. The therapy was quite well tolerated. The only side effects observed during treatment were: worse tolerance of physical effort, weight gain and slight edema of lower limbs. Due to the POM-DEX therapy, the patient achieved a durable response to the treatment, despite the rapid relapses of the disease during the previous lines of treatment.

Key words: multiple myeloma, pomalidomide, immunomodulatory drugs

Hematologia 2020; 11, 4: 235-239

\section{Wprowadzenie}

Szpiczak plazmocytowy (MM, multiple myeloma) jest nowotworem złośliwym układu krwiotwórczego charakteryzującym się nadmierną proliferacją i gromadzeniem monoklonalnych komórek plazmatycznych [1]. Stanowi około $10 \%$ wszystkich nowotworów hematologicznych, co sprawia, że jest drugim pod względem częstości występowania schorzeniem $z$ tej grupy [2]. Mediana wieku zachorowań w momencie diagnozy wynosi 60-65 lat. U większości pacjentów choroba postępuje lub nawraca mimo stosowania kolejnych linii leczenia, a mediana czasu przeżycia chorych $z$ objawową postępującą postacią choroby wynosi 5-7 lat [1]. Postępy w leczeniu MM, w tym wprowadzenie leków immunomodulujących (IMiD, immunomodulatory drugs) oraz inhibitorów proteasomu (PI, proteasome inhibitors), spowodowały wzrost odsetka odpowiedzi i wydłużenie czasu przeżycia pacjentów [3]. Jednak, mimo tego, choroba pozostaje nieuleczalna, a u większości pacjentów ostatecznie dochodzi do jej nawrotu $[3,4]$. Już w przypadku leczenia pierwszej linii czas trwania odpowiedzi u większości chorych nie przekracza 3 lat [5]. Leczenie pacjentów po kolejnym nawrocie pozostaje dużym wyzwaniem terapeutycznym, gdyż choroba jest zwykle wówczas bardziej agresywna, co skutkuje skróceniem czasu odpowiedzi na kolejne linie leczenia. Najgorsze rokowanie dotyczy chorych $z$ nawrotem MM, u których obserwowano wystąpienie oporności na lenalidomid i bortezomib, ponieważ w tym przypadku mediany czasu wolnego od progresji (PFS, progression-free survival) i przeżycia całkowitego (OS, overall survival) wynoszą odpowiednio zaledwie 5 i 9 miesięcy [5]. Ponadto u chorych po kilku intensywnych liniach terapii dochodzi do kumulacji efektów toksycznych leczenia [3].

Do leków stosowanych w leczeniu chorych na nawrotowego i opornego na leczenie MM należy lek immunomodulujący pomalidomid (Imnovid ${ }^{\circledR}$; Pomalyst ${ }^{\circledR}$ ). Jest on analogiem talidomidu, który — podobnie jak inne leki $z$ tej grupy — ma postać doustną [6]. Uważa się, że w jego działanie przeciwszpiczakowe jest zaangażowanych kilka mechanizmów - zarówno bezpośrednich, jak i pośrednich [7]. Bezpośrednie działanie przeciwnowotworowe wiąże się $z$ indukcją apoptozy poprzez szlak czynnika jądrowego $\kappa \mathrm{B}(\mathrm{NF} \kappa \mathrm{B}$, nuclear factor $\kappa B)$ i kaspazę 8. Ponadto pomalidomid hamuje adhezję komórek nowotworowych do komórek zrębu, wzmacnia odpowiedź limfocytów Th1, pobudza komórki naturalnej cytotoksyczności (NK, natural killer), tłumi proliferację limfocytów T regulatorowych (Treg), hamuje produkcję cytokin prozapalnych oraz działa antyangiogennie [8]. W 2013 roku pomalidomid został zatwierdzony przez amerykańską Agencja ds. Żywności i Leków (FDA, Food and Drug Administration) w leczeniu opornego oraz nawrotowego MM, a kilka miesięcy później dopuszczono go w tym wskazaniu na terenie Unii Europejskiej. Od listopada 2018 roku pomalidomid jest refundowany w 
Polsce w ramach programu lekowego do stosowania $\mathrm{w}$ trzeciej linia leczenia dla pacjentów $z$ nawrotowym i opornym na leczenie MM.

\section{Opis przypadku}

$\mathrm{Na}$ oddział hematologii zgłosiła się 66-letnia pacjentka $z$ rozpoznanym MM IgG lambda w stadium III, z 3 punktami według Międzynarodowego Indeksu Prognostycznego (IPSS, International Prognostic Scoring System). Wywiad chorobowy pacjentki był obciążony padaczką pourazową, nikotynizmem, otyłością, stanem po amputacji szyjki macicy oraz przebytym pólpaścem, ponadto w przeszłości u chorej wystąpiły potwierdzone radiologicznie złamania granicznych blaszek kręgów. Pacjentka od 3,5 roku była leczona $z$ powodu MM i dotychczas otrzymała pięć linii leczenia $z$ wykorzystaniem IMiD, bortezomibu i daratumumabu. Pierwszą linią leczenia zastosowaną u chorej był schemat oparty na bortezomibie, doksorubicynie oraz deksametazonie (PAD). Po 6 miesiącach stwierdzono brak odpowiedzi na tę terapię i przerwano podawanie leków pierwszej linii, po czym przez kolejne 6 miesięcy stosowano chemioterapię według schematu CTD (cyklofosfamid, talidomid, deksametazon), uzyskując bardzo dobrą odpowiedź częściową (VGPR, very good partial response). Po 3 miesiącach od zakończenia leczenia, po mobilizacji komórek CD34 $+z$ użyciem arabinozydu cytozyny oraz kondycjonowaniu szpiku $z$ zastosowaniem melfalanu, chora przebyła autologiczne przeszczepienie krwiotwórczych komórek macierzystych (auto-HSCT, autologous hematopoietic stem cell transplantation), po którym uzyskano VGPR. Mimo zastosowanego leczenia po 9 miesiącach u pacjentki obserwowano nawrót choroby. W kolejnej linii leczenia chora otrzymywała melfalan w połączeniu $z$ prednizonem (MP). Ze względu na progresję choroby $\mathrm{w}$ trakcie leczenia podawanie leków przerwano po 3 miesiącach. Następnie, po tej 3-miesięcznej przerwie, rozpoczęto leczenie daratumumabem, które zakończono po 5 miesiącach, ponownie nie uzyskując odpowiedzi. Jako leczenie kolejnej linii rozpoczęto terapię według schematu $z$ lenalidomidem oraz deksametazonem (RD). Nie obserwowano remisji choroby, w związku z czym leczenie przerwano po 3 miesiącach. Po zakończeniu leczenia u pacjentki utrzymywały się objawy pod postacią bólu kości, najbardziej nasilonego w odcinku lędźwiowo-krzyżowym kręgosłupa. Stężenie białka całkowitego utrzymywało się na poziomie $9,09 \mathrm{~g} / \mathrm{dl}$, natomiast białka monoklonalnego typu IgG lambda wynosiło $3,3 \mathrm{~g} / \mathrm{dl}$. Wyniki
Tabela 1. Wyniki badań morfologicznych oraz biochemicznych w momencie kwalifikacji do leczenia pomalidomidem Table 1. Morphological and biochemical parameters at the time of qualification for pomalidomide treatment

\begin{tabular}{lcc}
\hline Parametr & $\begin{array}{c}\text { Oznaczona } \\
\text { wartość }\end{array}$ & $\begin{array}{c}\text { Oznaczona wartość } \\
\text { względem wartości } \\
\text { referencyjnych }\end{array}$ \\
\hline WBC $\left[10^{3} / \mathrm{mm}^{3}\right]$ & 9,86 & $\mathrm{~N}$ \\
Limfocyty $\left[10^{3} / \mathrm{mm}^{3}\right]$ & 4,59 & $\uparrow$ \\
Neutrofile $\left[10^{3} / \mathrm{mm}^{3}\right]$ & 3,80 & $\mathrm{~N}$ \\
Hemoglobina $\left[\mathrm{g} / \mathrm{dl}^{3}\right.$ & 11,3 & $\mathrm{~N}$ \\
Płytki krwi $\left[10^{3} / \mathrm{mm}^{3}\right]$ & 179 & $\mathrm{~N}$ \\
Białko całkowite $[\mathrm{g} / \mathrm{dl}]$ & 9,09 & $\uparrow$ \\
Wapń [mmol/l] & 2,82 & $\uparrow$ \\
Kreatynina $[\mathrm{mg} / \mathrm{dl}]$ & 0,84 & $\mathrm{~N}$ \\
\hline
\end{tabular}

WBC (white blood cells) - krwinki białe/leukocyty; N - w normie; $\uparrow$ — wartość podwyższona

morfologii krwi oraz parametry biochemiczne przedstawiono $\mathrm{w}$ tabeli 1 . Chora pozostawała w dość dobrym stanie ogólnym, w skali sprawności według ECOG (Eastern Cooperative Oncology Group) została oceniona jako reprezentująca 2. stopień. Biorąc pod uwagę całokształt obrazu klinicznego, pacjentkę zakwalifikowano do dalszego leczenia pomalidomidem. 22 maja 2019 roku rozpoczęto podawanie pomalidomidu w dawce $4 \mathrm{mg} /$ dobę w cyklach 28-dniowych - lek podawano doustnie przez pierwsze $21 \mathrm{dni}$ cyklu, a następnie zalecono 7-dniową przerwę. Ponadto pacjentka otrzymywała deksametazon doustnie w dawce $40 \mathrm{mg} \mathrm{w} 1 ., 8$., 15. oraz 22. dobie cyklu. Przyjmowała również regularnie preparaty wapnia, cholekalcyferol, kwas zolendronowy, kwas acetylosalicylowy oraz pantoprazol — w ramach profilaktyki owrzodzeń żołądka i dwunastnicy wywołanym przez niesteroidowe leki przeciwzapalne (NLPZ).

W trakcie leczenia obserwowano znaczną redukcje stężenia białka monoklonalnego IgG lambda (tab. 2). Po otrzymaniu dwóch cykli terapii pacjentka spełniała kryteria remisji częściowej (PR, partial remission). Po 12 cyklach leczenia stężenie białka monoklonalnego obniżyło się o $78 \%$ względem okresu sprzed leczenia. Na rycinie 1 przedstawiono wyniki immunofiksacji $z$ okresu przed rozpoczęciem leczenia pomalidomidem oraz po otrzymaniu 12 cykli leczenia. Tolerancja leczenia była dość dobra - parametry hematologiczne utrzymywały się w normach odpowiednich dla płci i wieku. Funkcja nerek oraz pozostałe parametry biochemiczne również utrzymywały się na stałym poziomie. Jedynym objawem niepożądanym obser- 
Tabela 2. Stężenie białka monoklonalnego lgG lambda po kolejnych cyklach leczenia Table 2. IgG lambda monoclonal protein level after subsequent treatment cycles

\begin{tabular}{lcc}
\hline Ocena odpowiedzi na leczenie & $\begin{array}{c}\text { Stężenie białka } \\
\text { monoklonalnego }[\mathbf{g} / \mathbf{d l}]\end{array}$ & $\begin{array}{c}\text { Redukcja względem } \\
\text { poziomu wyjściowego }\end{array}$ \\
\hline Kwalifikacja do leczenia & 3,3 & - \\
Po 2. cyklu & 1,2 & $-63 \%$ \\
Po 4. cyklu & 0,8 & $-75 \%$ \\
Po 6. cyklu & 0,7 & $-78 \%$ \\
Po 8. cyklu & 0,7 & $-78 \%$ \\
Po 10. cyklu & 0,6 & $-82 \%$ \\
Po 12. cyklu & 0,7 & $-78 \%$ \\
\hline
\end{tabular}

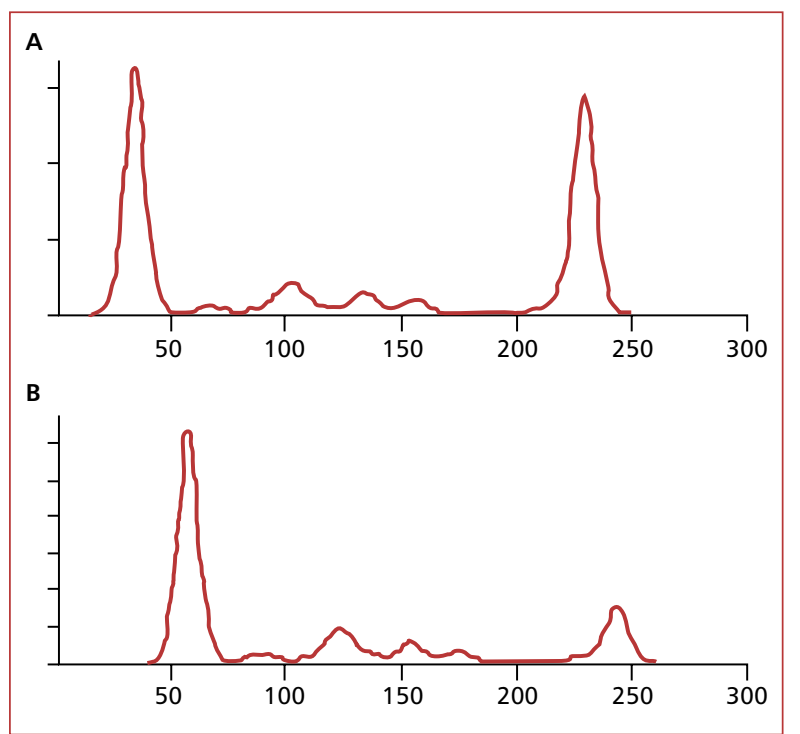

Rycina 1. Wyniki badania immunofiksacji: A. W momencie kwalifikacji do leczenia — stężenie białka monoklonalnego typu IgG lambda 3,3 g/dl; B. Po 12. cyklu terapii stężenie białka monoklonalnego typu lgG lambda $0,7 \mathrm{~g} / \mathrm{dl}$

Figure 1. Immunofixation: A. At the time of qualification for treatment - monoclonal protein IgG lambda $3.3 \mathrm{~g} / \mathrm{dL}$; B. After the $12^{\text {th }}$ cycle of therapy - monoclonal protein IgG lambda $0.7 \mathrm{~g} / \mathrm{dL}$

wowanym $\mathrm{w}$ trakcie leczenia była niska tolerancja wysiłku, ponadto wystąpiły zwiększenie masy ciała oraz niewielkie obrzęki podudzi. Ze względu na powyższe objawy rozpoznano jatrogenny zespó1 Cushinga i zmniejszono dawkę deksametazonu do $2 \mathrm{mg}$ w 1., 8., 15. oraz 22. dniu cyklu.

\section{Dyskusja}

Dzięki zastosowaniu schematu POM-DEX u pacjentki osiągnięto trwałą odpowiedź na lecze- nie, mimo szybkich nawrotów choroby w trakcie wcześniejszych linii leczenia. Pomalidomid pozostaje skuteczną opcją terapeutyczną w leczeniu chorych opornych na leczenie według schematów zawierającymi bortezomib, lenalidomid, daratumumab czy leki alkilujące. Skuteczność terapeutyczna doustnego pomalidomidu $\mathrm{w}$ skojarzeniu $\mathrm{z}$ deksametazonem u pacjentów $z$ nawrotowym i opornym na leczenie MM oceniano w dwóch dużych $(\mathrm{n}>220)$ randomizowanych, otwartych, międzynarodowych badaniach I/II fazy (MM-002) [9] oraz III fazy (MM-003; NIMBUS) [10]. W badaniu MM-002 udowodniono skuteczność terapii opartej na zastosowaniu pomalidomidu $z$ doustnymi małymi dawkami deksametazonu. Zastosowanie tego schematu terapii wpływało na wydłużenie PFS, OS oraz zwiększenie całkowitego odsetka odpowiedzi (ORR, overall response rate) w porównaniu ze stosowaniem pomalidomidu w monoterapii. Oporność na lenalidomid lub oporność zarówno na lenalidomid, jak i bortezomib nie wpływała na wyniki leczenia [9]. W badaniu NIMBUS porównywano zastosowanie dużych lub małych dawek deksametazonu w kombinacji $z$ pomalidomidem, udowadniając przewagę niskodawkowanych schematów terapii pod względem skuteczności, przy podobnym poziomie bezpieczeństwa terapii [10]. Wynik badania NIMBUS umożliwił rejestrację pomalidomidu, zarówno przez FDA, jak i Europejską Agencję Leków (EMA, European Medicines Agency). Skuteczność pomalidomidu podawanego lącznie $z$ małymi dawkami deksometazonu potwierdzono $\mathrm{w}$ prospektywnym badaniu II fazy, służącym ocenie zastosowania POM-DEX u pacjentów poddanych terapii trzeciego rzutu bezpośrednio po wcześniejszym nawrocie lub oporności na lenalidomid. W badanej populacji 89\% osiągnęło co najmniej stabilizację choroby, a wskaźniki hematologicznych zdarzeń niepożądanych były niższe niż w poprzednich badaniach, 
w których oceniano POM-DEX u pacjentów z nawrotowym lub opornym MM, a którzy otrzymali większą liczbę wcześniejszych schematów [11]. Dodatkowe wzmocnienie efektu terapeutycznego można uzyskać, dodając do schematu POM-DEX trzeci lek, na przykład bortezomib lub cyklofosfamid, co skutkuje niemalże podwojeniem odsetków odpowiedzi. Najlepsze efekty uzyskano w badaniach służących ocenie schematów trójlekowe opartych na POM-DEX $z$ wykorzystaniem nowych przeciwciał monoklonalnych (zarówno skierowanych przeciwko CD38, jak i SLAMF7) lub nowych leków, takich jak na przykład karfilzomib czy iksazomib [5]. W wieloośrodkowym, randomizowanym badaniu klinicznym III fazy OPTIMISMM wykazano istotne wydłużenie PFS u pacjentów leczonych kombinacją pomalidomidu, bortezomibu oraz deksametazonu [11]. W analizie wstępnej badania MM-014 dowiedziono skuteczności i bezpieczeństwa stosowania schematu POM-DEX w połączeniu $z$ daratumumabem, podawanego bezpośrednio po niepowodzeniu chemioterapii opartej na lenalidomidzie. W Stanach Zjednoczonych potrójna kombinacja pomalidomidu, daratumumabu i małej dawki deksametazonu została zarejestrowana $\mathrm{w}$ tym samym wskazaniu, co kombinacja pomalidomidu $z$ dubletem $\mathrm{w}$ małej dawce deksametazonu [12]. W Polsce pomalidomid jest zarejestrowany $\mathrm{w}$ leczeniu skojarzonym $z$ deksametazonem u dorosłych pacjentów z MM, u których stosowano uprzednio co najmniej jeden schemat leczenia zawierający lenalidomid.

\section{Podsumowanie}

Leczenie pomalidomidem $\mathrm{w}$ opisanym przypadku było stosunkowo dobrze tolerowane. W trakcie terapii pomalidomidem jest wymagane rutynowe monitorowanie parametrów hematologicznych i biochemicznych. Do najczęstszych powikłań hematologicznych leczenia POM-DEX należą neutropenia (48\%), niedokrwistość (33\%) oraz małopłytkowość (22\%). Do pozostałych częstych działań niepożądanych zaliczają się zapalenie płuc, bóle kości, zaburzenia czynności wątroby, zdarzenia zakrzepowo-zatorowe, zawroty głowy oraz ogólne osłabienie [10]. W opisanym przypadku występujące objawy niepożądane, wymagające zmniejszenia dawki, wiązały się $z$ zastosowaniem krotykosteroidów i obejmowały wystąpienie jatrogennego zespołu Cushinga.

Podsumowując, zastosowanie pomalidomidu w skojarzeniu $z$ małą dawką deksametazonu skutkowało osiągnięciem trwałej odpowiedzi oraz było związane $z$ dość dobrą tolerancją leczenia. Schemat POM-DEX jest skuteczna opcją terapeutyczną u pacjentów $z$ opornym lub nawrotowym i opornym na leczenie MM.

\section{Konflikt interesów}

Autorzy oświadczają, że nie występuje żaden konflikt interesów.

\section{Oświadczenie o świadomej zgodzie}

Uzyskano świadomą zgodę od pacjentki objętej badaniem. Pacjentka udzieliła świadomej zgody zgodnie $z$ Deklaracją Helsińską.

\section{Piśmiennictwo}

1. Giannopoulos K, Dmoszyńska A. Szpiczak plazmocytowy. In: Gajewski P, Szczeklik A. ed. Interna Szczeklika 2019/2020. Medycyna Praktyczna, Kraków 2019: 1045-1049.

2. Nowak WS, Skotnicki AB. Szpiczak plazmocytowy. In: Podstawy hematologii. Medycyna Praktyczna, Kraków 2019: 354-372.

3. Dimopoulos MA, Richardson PG, Moreau P, et al. Current treatment landscape for relapsed and/or refractory multiple myeloma. Nat Rev Clin Oncol. 2015; 12(1): 42-54, doi: 10.1038/ /nrclinonc.2014.200, indexed in Pubmed: 25421279.

4. Naymagon L, Abdul-Hay M. Novel agents in the treatment of multiple myeloma: a review about the future. J Hematol Oncol. 2016; 9(1): 52, doi: 10.1186/s13045-016-0282-1, indexed in Pubmed: 27363832 .

5. Giannopoulos K, Jamroziak K, Usnarska-Zubkiewicz L, et al. Zalecenia Polskiej Grupy Szpiczakowej dotyczące rozpoznawania i leczenia szpiczaka plazmocytowego oraz innych dyskrazji plazmocytowych na rok 2018/2019. Acta Haematol Pol. 2018; 49(4): 157-206, doi: 10.2478/ahp-2018-0024.

6. Celgene Corporation. POMALYST (pomalidomide) capsules, for oral use: US prescribing information. http://www.fda. gov (October 4, 2017).

7. Zhu YX, Kortuem KM, Stewart AK. Molecular mechanism of action of immune-modulatory drugs thalidomide, lenalidomide and pomalidomide in multiple myeloma. Leuk Lymphoma. 2013; 54(4): 683-687, doi: 10.3109/10428194.2012.728597, indexed in Pubmed: 22966948.

8. Lacy MQ, McCurdy AR. Pomalidomide. Blood. 2013; 122(14): 2305-2309, doi: 10.1182/blood-2013-05-484782, indexed in Pubmed: 23974193.

9. Richardson PG, Siegel DS, Vij R, et al. Pomalidomide alone or in combination with low-dose dexamethasone in relapsed and refractory multiple myeloma: a randomized phase 2 study. Blood. 2014; 123(12): 1826-1832, doi: 10.1182/blood-2013-11-538835, indexed in Pubmed: 24421329.

10. Miguel JS, Weisel K, Moreau P, et al. Pomalidomide plus low-dose dexamethasone versus high-dose dexamethasone alone for patients with relapsed and refractory multiple myeloma (MM-003): a randomised, open-label, phase 3 trial. The Lancet Oncol. 2013; 14(11): 1055-1066, doi: 10.1016/s1470-2045(13)70380-2, indexed in Pubmed: 29786478.

11. Richardson PG, Oriol A, Beksac M, et al. OPTIMISMM trial investigators. Pomalidomide, bortezomib, and dexamethasone for patients with relapsed or refractory multiple myeloma previously treated with lenalidomide (OPTIMISMM): a randomised, open-label, phase 3 trial. Lancet Oncol. 2019; 20(6): 781-794, doi: 10.1016/S1470-2045(19)30152-4, indexed in Pubmed: 31097405.

12. Siegel DS, Schiller GJ, Song KW, et al. Pomalidomide plus low-dose dexamethasone in relapsed refractory multiple myeloma after lenalidomide treatment failure. Br J Haematol. 2020; 188(4): 501-510, doi: 10.1111/bjh.16213, indexed in Pubmed: 31588567. 